\title{
REPRESENTAÇÃO HOMOERÓTICA FEMININA EM DUAS IGUAIS, DE CÍNTIA MOSCOVICH
}

\author{
Manuela Matté (Universidade de Caxias do Sul) \\ Salete Rosa Pezzi dos Santos (UFRGS)
}

Resumo: Este artigo analisa a presença de relações homoeróticas femininas representadas na obra Duas iguais (2004), de Cíntia Moscovich. Discutem-se questões relacionadas à sexualidade e homossexualidade femininas, bem como a existência de preconceito em função da exigência histórica e cultural de uma heterossexualidade compulsória para os homens e, principalmente, para as mulheres. Analisam-se, ainda, a partir da personagem protagonista Clara, questões relativas ao amor, ao erotismo e à subjetividade feminina.

Palavras-chave: Sexualidade Feminina, Homossexualidade Feminina, Preconceito, Amor.

Abstract: This paper analyses the presence of female homoerotic relations represented in the novel Duas iguais (2004), by Cíntia Moscovich. It discusses issues related to female sexuality and homosexuality, as well as the existence of prejudice due to the historical and cultural demand of a compulsory heterosexuality for men and mainly women. It analyses also issues related to love, eroticism and female subjectivity, from the perspective of the protagonist character Clara.

Key-words: Female Sexuality, Female Homosexuality, Prejudice, Love.

Nem sempre as questões relativas à sexualidade pertenceram à esfera da intimidade e da privacidade. Foi na Idade Moderna e com o aparecimento das sociedades burguesas que as práticas sexuais, ao contrário de épocas anteriores, passaram à necessidade de restrição ao âmbito privado, sendo vistas, muitas vezes, como sinônimo de 
reprodução e de prática secreta, devendo seguir certos modelos disciplinares (FOUCAULT, 2005). O intuito dessa restrição era controlar a sexualidade feminina, a infantil e a não-reprodutiva (FOUCAULT, 2005). Ao mesmo tempo em que a sexualidade passou a significar intimidade, porém, os discursos e os estudos sobre o sexo proliferaram-se. Inicialmente, esses estudos eram baseados no critério da normalidade e da anormalidade de comportamentos (SOHN, 2009), enquanto que os discursos definiam o sexo como uma espécie de prática pecaminosa que deveria ser detalhadamente confessada, conforme pressupunham instituições cristãs (FOUCAULT, 2005). A prática da confissão, para Foucault (2005, p. 26), embora parecesse censurar, apenas, "constituiu-se como uma aparelhagem para produzir discursos sobre o sexo, cada vez mais discursos, susceptíveis de funcionar e de serem efeito de sua própria economia". Em uma sociedade em que nunca se falou tanto sobre a sexualidade, os discursos sobre o sexo, logo, "não se multiplicaram fora do poder ou contra ele, porém lá onde ele se exercia e como meio para seu exercício" (FOUCAULT, 2005, p. 34). Sexo, para Foucault (1996), nesse sentido, está relacionado ao poder; esse último visto como um feixe aberto de relações, que podem tanto ocorrer de cima para baixo, como de baixo para cima. 
Foucault (1996, p. 244) encara a sexualidade como um dispositivo, "um conjunto decididamente heterogêneo que engloba discursos, instituições, organizações arquitetônicas, decisões regulamentares, leis, medidas administrativas, enunciados científicos, proposições filosóficas, morais, filantrópicas". Em meio a esse aparato histórico de regulação social de comportamentos, "cada sexo vê, portanto, que Ihe atribuem um papel exato e expressões autorizadas da sexualidade" (SOHN, 2009, p. 119), sendo que as maiores prejudicadas foram as mulheres, uma vez que, por muito tempo, histórica e cientificamente, atribuiu-se a elas uma sexualidade atrelada unicamente à função reprodutiva. Giddens (1993) afirma que a sexualidade feminina foi ora colocada na esfera histérica e patológica, ora na esfera privada da reprodução, aliada aos ideais da família, do lar, dos laços matrimoniais.

O rompimento com essa analogia entre sexualidade feminina e função materna ocorreu, embora lentamente, a partir do início do século XX. A publicação da obra freudiana Três ensaios sobre a sexualidade (1905), cujas afirmações são, hoje, em grande parte, questionadas, contribuiu para esse rompimento. Freud (1970) instituiu o prazer como parte integrante da sexualidade. A sexologia desenvolveu- 
se, mais enfaticamente, no período entre guerras e, apesar de ter promovido avanços durante o decorrer do século passado, ainda se manteve bastante presa ao modelo de dois gêneros, modelo que tomava o sexo feminino em detrimento do masculino (SOHN, 2009). Na década de 1960, por exemplo, “66\% dos jovens na faixa de 16-24 anos julgam que as relações pré-nupciais são 'normais' ou mesmo 'úteis' para os rapazes, mas $83 \%$ as consideram 'perigosas' ou 'censuráveis' para as moças" (SOHN, 2009, p. 143). Dados como esses confirmam que o campo da sexualidade era, ainda em meados do século $X X$, restrito aos homens, negado às mulheres.

É nesse sentido que Butler (2008) afirma que, ao longo da história da sexualidade, construiu-se uma noção compulsória de heterossexualidade atrelada ao binarismo masculino/ feminino. A origem da expressão heterossexualidade compulsória é atribuída à Adrienne Rich (1980). Segundo a autora, a dominação masculina reforça a heterossexualidade compulsória, principalmente para as mulheres, procurando convencê-las, através da força física (uso do cinto de castidade, por exemplo) ou através de um controle da consciência (idealização do casamento heterossexual na arte, na literatura e no cinema, por exemplo), de que a compulsoriedade heterossexual é inevitável para elas (RICH, 1980). 
Tudo isso contribuiu para a formação, cultural e histórica, de um sistema sexo/gênero, uma "constituição simbólica sóciohistórica, modo essencial, através do qual uma realidade social se organiza, divide-se e é vivenciada simbolicamente, a partir da interpretação das diferenças entre os sexos, prisma através do qual se lê uma identidade incorporada, modo de ser no e de vivenciar o corpo" (CAMPOS, 1992, p. 111). Para Campos (1992), os sistemas sexo/gênero produziram, culturalmente, mas com o pretexto da diferença biológica, uma diferença hierarquizada entre os sexos.

Para Bourdieu (2007), a sexualidade é uma invenção histórica, indissociável dos campos religioso, jurídico e burocrático. O par binário masculino/feminino é uma estrutura histórica que mantém relação homóloga com outros pares derivados desse: dominante/dominado, acima/ abaixo, ativo/passivo (BOURDIEU, 2007). De acordo com Sohn (2009, p. 121), mesmo com o avanço da sexologia, muitos estudiosos "raciocinam através do binômio feminino/ masculino e seus complementos implícitos: passiva/ativo, iniciada/iniciador, conquistada/conquistador. A sexualidade feminina é a principal vítima dessa leitura distorcida". Surgem, a partir desses pares binários, relações estruturais de dominação sexual, atrelando, novamente, sexo a poder. 
A proliferação de discursos sobre o sexo nos séculos XIX e XX de que fala Foucault (2005) foi intensa e gerou, além de práticas discursivas que priorizavam o matrimônio heterossexual, discursos sobre as perversões sexuais, nos quais a irregularidade sexual foi anexada à categoria de desvio e de doença mental (FOUCAULT, 2005). De acordo com Foucault (2005), antes do século XIX, o foco dos discursos sobre sexualidade era a relação matrimonial, negligenciando-se, por exemplo, práticas de sodomia e de sexualidade infantil, elementos condenáveis por serem contra natura. A partir do século XIX e XX, porém, tomam a palavra as heterogeneidades sexuais, não menos condenadas do que antes, todavia: "no decorrer do século eles carregaram sucessivamente o estigma da 'loucura moral', da 'neurose genital', da 'aberração do sentido genésico', da 'degenerescência' ou do 'desequilíbrio psíquico'." (FOUCAULT, 2005, p. 41). Os discursos sobre as sexualidades periféricas, no entanto, não se constituíram apenas de condenações ou de proibições, e, de acordo com Foucault (2005), esses discursos não tornaram as sociedades modernas mais repressivas e proibitivas do que as anteriores, pelo contrário, contribuíram para que, cada vez mais, se falasse sobre sexo. 
Dentro das sexualidades periféricas que começaram a vir à tona nos discursos, a homossexualidade recebeu ênfase. Homossexualidade ou homoerotismo, de acordo com Costa (1992), refere-se à atração entre sujeitos do mesmo sexo e constitui-se de uma experiência geralmente desvalorizada. Essa desvalorização deve-se, principalmente, às representações sociais sobre a sexualidade que, historicamente, têm exigido uma correspondência exata entre sexo e gênero, fazendo com que não só mulheres, mas também homens e homossexuais sejam prisioneiros dos sistemas sexo/gênero (CAMPOS, 1992; LAURETIS, 1994). De acordo com Wittig,

a sociedade heterossexual é a sociedade que não oprime somente lésbicas e homossexuais, ela oprime muitos diferentes/outros; oprime todas as mulheres e muitas categorias de homens, todas e todos que estão na posição de serem dominados. Constituir a diferença e controlá-la é um ato de poder, já que, essencialmente, este é um ato normativo. (WITTG, 1992, p. 29 - tradução nossa)

Sobre a história da homossexualidade, Sohn (2009, p. 146) afirma não ser linear, "pois alterna avanços e recuos, da mesma forma que a repressão continua na ordem do dia ao longo de todo o século XX." Em Portugal, muito do que 
se sabe sobre a história das práticas homossexuais se deve à Inquisição portuguesa que, desde o século XVI, "passou a julgar determinados delitos morais, certos desvios de conduta familiar ou sexual que, por vários meios e modos, foram considerados heresias" (VAINFAS, 2008, p. 117). Dentre essas heresias, a prática da sodomia - entendida ora como a relação de cópula entre homens ou entre homens e mulheres, ora como homoerotismo tanto entre homens quanto entre mulheres - era a mais perseguida, considerada “abominável pecado nefando" (VAINFAS, 2008, p. 117). Durante o século XVI, a maioria dos inquisidores acreditava ser a sodomia praticável somente entre homens, poucos a consideravam pecado cometido também por mulheres ${ }^{1}$. A partir do século XVII, os inquisidores portugueses, mais por desprezo e misoginia do que por solidariedade às mulheres, passaram a investigar somente casos de sodomia entre homens, pois esses eram os casos que realmente importavam e mereciam atenção.

No Brasil, as relações homoeróticas entre mulheres, embora existentes, eram menos visíveis, "elas construíam verdadeiros romances secretos que envolviam mulheres das mais variadas posições sociais" e, consequentemente,

1 As dúvidas quanto à classificação da sodomia deviam-se, principalmente, ao fato de não existir, entre os inquisidores, um acordo quanto à necessidade, ou não, de haver a penetração fálica para que o ato fosse considerado sodomita (VAINFAS, 2008). 
sofreram menos processos do que as mesmas relações entre os homens (VAINFAS, 2008, p. 133). Durante a primeira visitação do Santo Ofício ao nordeste brasileiro, no século $\mathrm{XVI}$, de vinte e nove mulheres acusadas, sete mulheres responderam a processo inquisitório por sodomia e apenas três foram punidas (VAINFAS, 2008). Graças às confissões realizadas por elas aos inquisidores é que se têm registros da existência da homossexualidade feminina em terras brasileiras já no início da colonização, embora essas práticas tenham sido vistas de forma discriminatória pelos inquisidores, que eram desdenhosos em relação à sexualidade feminina (VAINFAS, 2008). Além disso, a opacidade das narrativas inquisitoriais misóginas sobre a sexualidade feminina não nos permite ir muito além da confirmação da existência das relações homoeróticas, sendo necessário recorrer a outros documentos para que se tenha uma percepção maior de como essas relações ocorriam:

Seja como for, o certo é que relações homoeróticas entre as mulheres quase não são perceptíveis nos papéis da Visitação quinhentista. E não é improvável que elas mesmas tenham contribuído para este obscurecimento da própria sexualidade. Consternadas, instadas a falar diante de homens estranhos e poderosos sobre intimidades secretíssimas e delituosas, foram 
possivelmente reticentes e evasivas em seus relatos. (VAINFAS, 2008, p. 136, grifo do autor)

Uma maior tolerância às práticas homossexuais, tanto masculinas quanto femininas, só começaria a ocorrer séculos depois, no século $X X$, embora a homofobia ainda fosse bastante visível nesse período, estendendo-se durante as guerras mundiais, quando os homossexuais enfrentaram forte perseguição, até a década de 1970, quando ainda eram considerados doentes pelas ciências médicas (SOHN, 2009). Somente após essa década ${ }^{2}$ é que se proliferaram os movimentos gays reivindicando direitos e mudanças na legislação.

Alfred Kinsey (1955) foi um dos pioneiros, em meados do século $X X$, ao promover estudos sobre a sexualidade masculina, a feminina e a homossexualidade, contribuindo para tirá-las do status de desvio, pecado ou anormalidade. Ao contrário de Freud (1970), que acreditava ser a libido uma característica exclusivamente masculina, Kinsey (1955) afirmou que a sexualidade feminina era bastante semelhante à masculina, inclusive no que diz respeito às sensações de prazer.

2 No Brasil, na década de 1970, houve a primeira publicação de uma coluna gay no jornal Última Hora, de grande circulação, à época (MOTT, 1987). Em 1978, iniciou-se a primeira organização pelos direitos dos homossexuais, o grupo "Somos: grupo de afirmação homossexual” (GREEN, 2000). 
Assim como Foucault (2005) afirma ser necessário questionar-se acerca das postulações estabelecidas como verdades absolutas, Fry e Macrae (1991, p. 120) acreditam que não se pode falar em verdades absolutas quando se trata da homossexualidade, pois se trata de um fato social:

partiremos do pressuposto de que não há nenhuma verdade sobre o que é a homossexualidade e que as ideias e práticas a ele associadas são produzidas historicamente no interior das sociedades concretas e que são intimamente relacionadas com o todo destas sociedades (FRY; MACRAE, 1991, p. 10).

Para os autores, há tantas maneiras de representar e praticar a homossexualidade quanto há relações sociais, históricas e culturais (FRY; MACRAE, 1991). Bourdieu (2007) compartilha da ideia de que heterossexualidade e homossexualidade são construtos sociais e acredita que, a fim de questionar essas verdades absolutas culturalmente estabelecidas, a história deveria

empenhar-se particularmente em descrever e analisar a reconstrução social, sempre recomeçada, dos princípios de visão e de divisão geradores dos "gêneros" e, mais amplamente, das diferentes categorias de práticas sexuais (sobretudo heterossexuais e homossexuais), sendo a própria heterossexualidade construída socialmente e socialmente constituída 
como padrão universal de toda prática sexual "normal", isto é, distanciada da ignomínia da "contranatureza". (BOURDIEU, 2007, p. 102)

Há, portanto, diversas maneiras tanto de vivenciar como de repreender as manifestações homossexuais, e, atualmente, não se pode mais pensar o mundo apenas como uma oposição entre homossexuais e opressores (FRY; MACRAE, 1991); porém, não se pode negar a existência histórica do preconceito e da violência simbólica contra os homossexuais. Segundo Souza (2004), a violência articulada simbólica não se dirige a qualquer ser social, mas contra categorias sociais específicas construídas historicamente, como, por exemplo, os negros, os judeus, os homossexuais. Estes sofrem, de acordo com Bourdieu, uma forma particular de dominação simbólica:

A forma particular de dominação simbólica de que são vítimas os homossexuais, marcados por um estigma que, à diferença da cor da pele ou da feminilidade, pode ser ocultado (ou exibido), impõe-se através de atos coletivos de categorização que dão margem a diferenças significativas, negativamente marcadas, e com isso a grupos ou categorias sociais estigmatizadas. Como em certos tipos de racismo, ela assume, no caso, a forma de uma negação da sua existência pública, visível. (BOURDIEU, 2007, p. 143) 
Para Mott (2000), os homossexuais são os mais odiados dentre todas as minorias. Segundo o autor, a maior parte dos homossexuais, em função da discriminação, não assume sua orientação sexual, tampouco o sentimento de amor, motivo de orgulho e de expressão para os casais heterossexuais. Os avanços para a contenção da homofobia - uma forma de preconceito (percepções mentais negativas) que pode, ou não, gerar discriminação (materialização, nas relações sociais, das percepções mentais) (RIOS, 2007) -, embora tenham se beneficiado dos movimentos promovidos por grupos homossexuais, feministas ${ }^{3}$ e até mesmo de esquerda, ainda enfrentam retrocessos.

Dentre esses retrocessos encontra-se o fato de que a homossexualidade feminina, historicamente, foi mais rejeitada, reprimida e ocultada do que o homoerotismo masculino. De acordo com Rich (1980), a experiência lésbica, na literatura e na ciência, foi, por muito tempo, vista como desvio e aberração, e, às vezes, tratada com invisibilidade e negligência pelos próprios discursos feministas. Como uma maneira de garantir a dominação física, econômica e emocional masculina, a heterossexualidade compulsória feminina é reforçada quando se marginaliza ou se procura

3 De acordo com Fry e Macrae (1991), inicialmente, não só no Brasil, mas também em outros países, os grupos de lésbicas enfrentaram repressão por parte de grupos feministas. Hoje, pelo contrário, as causas feministas contemplam também as reivindicações homossexuais. 
tornar invisível a mulher homossexual. Questionar o discurso que coloca a heterossexualidade feminina como preferência ou escolha subjetiva das mulheres é uma maneira de desfazer silêncios e explorar novos caminhos no que tange à sexualidade feminina ( $\mathrm{RICH}, 1980)$.

A homossexualidade feminina, de acordo com Rich (1980, p. 650), é diferente da masculina: "percebo a experiência lésbica como sendo, assim como a maternidade, uma profunda experiência feminina, com opressões particulares, significados e potencialidades que não podemos compreender enquanto simplesmente a agruparmos a outras sexualidades existentes estigmatizadas"4. Dentro das opressões particulares de que fala Rich (1980), está a imposição da heterossexualidade feminina. Diante dessa imposição, muitas mulheres casam-se com homens, ou mantêm uma "vida dupla" (RICH, 1980, p. 654), a fim de parecerem "normais", mesmo quando apaixonadas por outras mulheres.

É o caso da protagonista da obra Duas iguais (2004), de Cíntia Moscovich ${ }^{5}$. Clara, jovem judia pertencente a uma

4 Do original: "I perceive the lesbian experience as being, like motherhood, a profoundly female experience, with particular oppressions, meanings, and potentialities we cannot comprehend as long as we simply bracket it with other sexually stigmatized existences" (RICH, 1980, p. 650).

5 Escritora contemporânea de origem judaica, Cíntia Moscovich tem se destacado na literatura brasileira, fato atestado pelos inúmeros prêmios recebidos, importantes para a literatura sul-rio-grandense. Dentre eles, destaca-se o primeiro lugar conquistado no Concurso de Contos Guimarães Rosa, instituído pelo Departamento de Línguas Ibéricas da Radio France 
comunidade regional judaica, em Porto Alegre, à época da ditadura militar, vive uma relação homoafetiva com sua amiga de escola, Ana. A protagonista, no entanto, é incapaz de assumir publicamente seu desejo e acaba optando por um casamento heterossexual com Vítor, judeu e neto de rabino, funcionário da construtora do falecido pai de Clara. Inicialmente procurando encontrarem-se às escondidas, logo as duas descobrem que a forte amizade entre elas não está sendo bem vista pelos pais, principalmente os de Clara, e pelos colegas da escola. Decidem, então, continuar relacionandose, mas não em locais públicos. Clara percebe que o pai, apesar de não fazer perguntas - "ele não perguntava o que já sabia e também sabia que duas meninas não suportariam uma situação clandestina por muito tempo" -, é contra a crescente amizade entre elas: "meu pai se tornara agressivo. Dizia que eu andava em más companhias" (MOSCOVICH, 2004, p. 42). Mesmo diante da desaprovação do pai, que solicitou à diretora da escola que as meninas não ficassem na mesma classe, Clara continua, ainda por um tempo, o relacionamento com Ana.

O motivo que leva Clara e Ana à decisão de afastaremse, contudo, não é decorrente das relações familiares. A 
grande decepção ocorre diante da repressão social, no dia em que Beatriz, colega de escola, faz a seguinte pergunta preconceituosa na frente dos demais colegas: "Qual de vocês é o homem?" (MOSCOVICH, 2004, p. 45). Cabe, aqui, investigar, nessa pergunta, além do visível teor discriminatório, a razão que faz com que, na relação homossexual entre mulheres ou entre homens, um dos parceiros precise assumir o papel de macho/ativo e o outro de fêmea/passivo. Novamente, aqui, atuam os sistemas sexo/gênero, que pressupõem uma heterossexualidade compulsória, mesmo nas relações homossexuais. A pergunta de Beatriz revela a necessidade da existência de uma dominação masculina entre as duas mulheres, já que, socialmente, a relação sexual também é vista como dominação do masculino sobre o feminino, sendo a igualdade impossível. Segundo Bourdieu,

se a relação sexual se mostra como uma relação social de dominação, é porque ela está construída através do princípio de divisão fundamental entre o masculino, ativo, e o feminino, passivo, e porque este princípio cria, organiza, expressa e dirige o desejo - o desejo masculino como desejo de posse, como dominação erotizada, e o desejo feminino como desejo da dominação masculina, como subordinação erotizada, ou mesmo, em última instância, como reconhecimento erotizado da dominação. (BOURDIEU, 2007, p. 31) 
Dessa forma, mesmo que no entendimento de Clara e de Ana não houvesse dominação e, para elas, ambas fossem dotadas de uma sexualidade feminina - "nenhuma de nós era homem, nenhuma de nós, ela estava escutando direito?" (MOSCOVICH, 2004, p. 45) -, para a sociedade eram "duas meninas lésbicas [...] era isso a que estávamos reduzidas" (MOSCOVICH, 2004, p. 41), sendo que uma das duas deveria assumir o papel de macho/ativo da relação. O preconceito dos colegas, a partir de então, aumenta: "uma nova fase se instalara. Tínhamos sido delatadas. Os colegas, percebendo o que não podíamos esconder, começaram a falar. A falar, a observar e a rir. Por que riam de nós?" (MOSCOVICH, 2004, p. 46).

Diante do preconceito, Clara e Ana optam pelo afastamento até começarem a faculdade. Entretanto, Ana decide cursar a faculdade na França, pois já não consegue ficar perto de Clara sem poder assumir seu amor por ela. Clara permanece em sua comunidade, em Porto Alegre, vivendo com a família. Diante da morte do pai, ficara incumbida de cuidar dos irmãos. Recebe, após o enterro do pai, uma ligação telefônica de Paris. A breve conversa com Ana reacende o amor e a saudade que ambas sentem uma pela outra, mas é interrompida com um "adeus, como uma pedra" (MOSCOVICH, 2004, p. 93). 
Clara forma-se jornalista e recebe um convite do paraninfo de formatura para trabalhar em um jornal. Após momentos de indecisão, aceita a proposta e começa a trabalhar. Faz amizade com os colegas de trabalho, em especial, com Natália. Apesar do visível interesse homoafetivo de Clara por Natália, é com Vítor que se desenrola o segundo relacionamento afetivo da vida da protagonista. Vítor era arquiteto e conhecera Clara em um dos lançamentos da construtora da família dela. O rapaz logo mostrou interesse por ela, e a família de Clara demonstrou bastante simpatia pelo fato de ser judeu. Embora demonstrasse afeto pelo rapaz, Clara questionava-se se aquilo era paixão: "bons sentimentos, todos inocentes, é o máximo que ele me desperta, creio. Mas paixão? Paixão?" (MOSCOVICH, 2004, p. 118 - grifo do autor). Mesmo assim, em meio a noites de sono em que se lembrava de Ana, Clara aceita o pedido de casamento de Vítor, talvez devido a "uma vontade de, enfim, destinar-me a alguém e, portanto, de caber naquela proposta" (MOSCOVICH, 2004, p. 129). Em nenhum momento, porém, Clara confirma amar Vítor: "eu o amava? E como eu poderia saber? Naquela hora, somente ele tinha certezas e, portanto, era o único de nós que podia dormir" (MOSCOVICH, 2004, p. 131). 
Vítor e Clara casam-se e, após alguns anos morando juntos, Clara recebe, novamente, um telefonema de Ana. Dessa vez, ela está no Brasil, e as duas combinam encontrarse. Clara mente para o marido e esconde a decisão de rever a amiga. Nas páginas que seguem, a protagonista-narradora descreve o encontro, marcado por sensualidade, amor e erotismo. Nesse momento, as duas amigas finalmente cedem aos seus desejos homoeróticos, deixam aflorar suas sexualidades e entregam-se uma a outra, em igualdade, confessando que se amavam:

Não pude ver além, eu me desesperava, a divindade de carne e de formas redondas, e tu não me dizias nada, me enlaçavas no duro e possante abraço, me afogando na pedra dos teus seios, a pedra da memória, que nunca mais vou esquecer, a pele pedra pintalgada de tom rosa, cortada no fundo de azuis. E, como ansiasse por te sentir, me despiste, me descobriste, o desejo flutuando ali, à flor. O desmaio de ver teu seio no meu seio, a turgidez dos bicos, tua rosa rasgando a minha pele, vergões sulcos. E tua mão de unhas curtas espalmada no meu ventre, o toque de teus ossos, tuas cartilagens afundando em mim, o frio contra o calor, os dedos me penetrando aquosos, deslizando no desejo que me emanava, e sorriste porque a vida inteira sorriste ao constatar o efeito que tinhas em mim. (MOSCOVICH, 2004, p. 153) 
A intensidade da relação homoafetiva entre as duas iguais, entretanto, é mais uma vez prejudicada, visto que Clara, abdicando de sua subjetividade, opta por afastar-se, novamente, de Ana: "não pude te dizer, Ana, não pude te dizer, mas eu tinha de ir embora, minha vida nunca pôde ser contigo e me esperava longe de ti" (MOSCOVICH, 2004, p. 155). Clara volta a sua relação heterossexual, com a sensação perturbadora de que traíra Vítor.

Por mais algum tempo, Clara conseguiu esconder seu passado do marido, até que Beatriz, agora colega de trabalho de Vítor, contou a ele sobre a amizade íntima de Clara e Ana, nos tempos de escola. Apesar de incomodado, Vítor procurou manter o relacionamento como se nada tivesse acontecido. Porém, no momento em que Ana, às vésperas de uma cirurgia grave, em função de uma má formação cerebral, liga para Clara e pede a ela que a encontre, Clara, finalmente, admite, ao conversar com o marido, que sempre fora apaixonada pela amiga e que estava disposta a reencontrá-la. Finalmente assumindo-se enquanto sujeito e realizando uma escolha por si mesma, os últimos capítulos de Duas iguais destinam-se a revelar a intensidade do amor homoerótico de Clara por Ana, um amor recíproco que, ambas percebem, demanda expressão. 
A presença do amor na vida de Clara, protagonista do romance em análise, é importante, à medida que significa tanto a construção da sua subjetividade quanto da sua identidade. Segundo Giddens (1993), há dois tipos de amor: o romântico e o apaixonado. O primeiro, histórica e culturalmente associado à ideia de casamento, trata-se de um amor que não é, necessariamente, acompanhado de desejo sexual e que tem sido visto como feminizado, ligado à criação do lar, às relações entre pais e filhos e à maternidade. Assim, o amor romântico é "um amor de companheiros, ligado à responsabilidade mútua de maridos e esposas pelo cuidado da família ou da propriedade" (GIDDENS, 1993, p. 54). O segundo, também chamado "amor-paixão", seria uma ligação entre o amor e o sexo e, portanto, perturbador, fervoroso e, do ponto de vista social, perigoso.

Clara parece vivenciar ambos os tipos de amor propostos por Giddens (1993): o amor romântico e o amor-paixão. O primeiro coincide com a experiência matrimonial heterossexual que ela vive com Vítor. A família da jovem judia enxerga no casamento com o rapaz uma possibilidade de constituição de família, de ascensão social (pois Vítor daria continuidade aos negócios do pai de Clara) e de cumprimento da tradição religiosa judaica, em que moças judias se casam 
com moços judeus, preferencialmente. Influenciada pela família, mas também numa tentativa de fuga do verdadeiro amor e na busca de esquecê-lo, Clara encontra no casamento heterossexual o amor romântico, o mesmo amor que uniu seu pai e sua mãe, um casal que constituiu família, cuidou da propriedade e perpetuou os preceitos judaicos.

Não é o casamento com Vítor, no entanto, que constitui a principal vivência amorosa da vida da protagonista. Clara vivencia o amor-paixão, o amor enquanto sentimento em si, com Ana, colega da escola. Inicialmente, a relação entre as amigas não é percebida - pelo menos da parte de Clara como uma relação homossexual:

- Aninha, o que está acontecendo? Existe alguma coisa errada com a gente?

- Ou talvez muito certa, quem sabe? Você ainda não se deu conta?

Eu odiava aquelas respostas-perguntas que ela pronunciava com ar superior. Me dar conta do quê? O que ela sabia e que não me revelava? Qual era o grande mistério que a mente superior dela já havia desvendado? (MOSCOVICH, 2004, p. 34-35)

$\mathrm{Na}$ verdade, Clara acredita sentir por Ana uma forte amizade. Essa dedução da protagonista pode ser explicada pela crença de que, muitas vezes, amizade e amor são tidos como sentimentos muito parecidos. Paz (1994) afirma que 
a semelhança está no fato de que ambos estão baseados na escolha e na exclusividade. A distinção ocorre no momento em que a relação sexual, o elemento carnal, passa a integrar a relação entre amigos (PAZ, 1994). No início, Clara não entende o que está acontecendo entre elas, porque ainda não houve a relação carnal, portanto, não sabe se o que sente é amizade ou algo maior. O mistério de que Clara fala, porém, já está solucionado para a subjetividade de Ana desde o início da amizade das duas. Clara somente percebe que se trata de uma relação homoafetiva a partir do momento em que os colegas as expõem na frente de toda a escola, perguntando qual das duas é o homem do relacionamento. Essa é a visão da sociedade diante das amigas, mas o que elas sentem é a experiência de um grande amor: «o pensamento de que beijaria alguém com verdade me preencheu. Ela era o meu primeiro amor. Eu intuía. Eu queria" (MOSCOVICH, 2004, p. 37, grifo nosso).

Clara, atingida pela flecha de Eros, passa a descobrir, ao lado da amada, os prazeres do amor-paixão. De acordo com Conche,

a relação sensorial e sensível dos que se amam pretende ser uma linguagem. Os gestos do desejo não visam despertar o desejo do outro e seu prazer, senão para convidá-lo a explorar juntos um país e uma paisagem desconhecidos, como se se tratasse de descobrir juntos os mistérios de uma floresta profunda. $\mathrm{O}$ 
que assim descobrimos, numa espécie de percepção e de emoção compartilhadas, é um mundo de sensações inéditas, indefinidas e surpreendentes. Está-se fora da cotidianidade da vida, numa espécie de jubilação e de êxtase sensorial. (1998, p. 13-14)

Segundo Beauvoir, é possível falarmos em igualdade nos relacionamentos homoeróticos entre mulheres:

entre mulheres, o amor é contemplação: as carícias são menos destinadas a se apropriar do outro do que a recriar-se lentamente através dele; a separação está abolida, não há nem luta, nem vitória, nem derrota; dentro de uma exata reciprocidade cada qual é ao mesmo tempo sujeito e objeto, a soberana e a escrava; a dualidade é cumplicidade. (BEAUVOIR, 1980, p.156)

Os momentos ao lado de Aninha são únicos e prazerosos, capazes de unir amor e erotismo, baseados na doação recíproca e na igualdade:

Também aprendi que o grande segredo era ter prazer em proporcionar prazer. $\mathrm{O}$ prazer passou a ser uma dádiva de vida. Eu a amava, eu lhe disse isto, e Aninha me silenciou com um novo beijo, enquanto seguia o movimento ritmado. Me olhou, apoiada nas palmas das mãos, e pediu que eu me desse conta de que, naquela hora, éramos duas mulheres se amando e que nunca duas pessoas poderiam 
ser tão iguais. [...] Ela me fazia feliz. Balbuciou que me amava. (MOSCOVICH, 2004, p. 40, grifo nosso)

No entanto, a flecha de Eros trouxe não só ventura, mas também desventura para as duas amigas. As relações amorosas, na maioria das vezes, engendram conflitos e sofrimento, são inúmeras as obras literárias ${ }^{6}$ em que os amores estão fadados à dor. Para Paz (1994), o principal motivo do sofrimento amoroso é o tempo, ou seja, a certeza da morte humana, que impossibilita a eternidade. Quando Clara, finalmente, decide enfrentar o preconceito, separarse do marido e assumir o seu amor por Ana, a morte é o elemento que impossibilita a realização amorosa. De acordo com Conche (1998), a morte é a única inimiga do amor. Para Bauman (2004, p. 23), amor e morte são experiências únicas, dois acontecimentos incompreensíveis que não podem ser previstos: "o amor pode ser, e frequentemente é, tão atemorizante quanto a morte». Clara, durante toda a sua juventude, teme entregar-se a um relacionamento com Ana. Talvez o sofrimento, a certeza do erro cometido e o temor da possibilidade de nunca mais rever Ana tenham contribuído para que Clara, por fim, assumisse seu sentimento e recomeçasse sua relação amorosa:

6 Lembremos Os sofrimentos do jovem Werther, de Goethe, de 1774. 
Há sempre a possibilidade de pôr a culpa numa escolha, considerando-a equivocada, e não na incapacidade de aproveitar as oportunidades por ela oferecidas, pelo fato de a bemaventurança prevista não ter conseguido se materializar. Há sempre uma chance de abandonar a estrada pela qual se chegaria à realização e recomeçar - mesmo que a partir do zero, se as perspectivas parecerem atraentes. (BAUMAN, 2004, p. 74)

A protagonista decide recomeçar sua relação com Ana, uma vez que não consegue mais sustentar sua relação com o marido. Após a ligação de Ana, às vésperas da cirurgia que envolve risco de morte, Vítor questiona a esposa sobre o porquê de tamanha preocupação. A conversa entre o casal é um dos únicos momentos em que Clara deixa transparecer seu verdadeiro desejo:

- E você vai vê-la?

Sim, afirmei com toda a convicção que me faltara durante a vida. Ele adivinhou:

- Você nunca deixou de querer esta moça, não é assim?

Por misericórdia, por lealdade, por sei eu que espécie de sentimentos, concordei, ele tinha razão, eu a queria. E logo depois, como quem corrige uma grande falta, emendei: eu a queria muito. [...] As palavras, ainda que breves, aliviaram-me, tornaram-se transparentes, a luz passava através delas; não mais o anteparo 
opaco, não mais as virtudes nebulosas da fantasia. (MOSCOVICH, 2004, p. 205)

Nos momentos que se seguem, a narrativa apresenta o amor-paixão vivenciado por elas nos últimos dias de vida de Ana. Trata-se de um amor que a protagonista jamais sentira ao lado do marido. Um amor que, além de erótico, possui características que o fazem parecer sublime, divino: "teus olhos e teu rosto, Aninha, teu rosto irmão do divino, o ato criativo em tuas feições; anjo meu, mensageira redentora, rainha dulcíssima" (MOSCOVICH, 2004, p. 220). Clara arrepende-se de não ter insistido na relação das duas durante a adolescência: "ao vê-la ali tive noção exata do engodo a que me submetera: o tempo sem ela fora um tempo errado" (MOSCOVICH, 2004, p. 212). O desespero diante da iminente morte alheia faz com que Clara assuma para si mesma e para Ana que sempre a amara. O sofrimento e o arrependimento de não ter aproveitado os anos anteriores ao lado da amada deixam em Clara a sensação de uma vida não vivida plenamente:

Relembrei os dias de meu exílio sem ti, reverti fim e início, manhã e noite, as horas para trás; dias tortos, incompletos, sem arremates, dias que não foram meus, a lembrança tornando-me visitante ocasional de minha própria história; eu feito uma assombração minha. Não me servia um só dia do passado e descarteios porque não eram meus, porque 
não estavas; pensava que, tampouco adiante, não me serviriam as horas da vida sem o sacramento de tua existência. (MOSCOVICH, 2004, p. 219-220)

Clara acompanha Ana durante os momentos finais de sua existência, as duas têm relação sexual ainda uma vez e trocam as três palavras tão difíceis, na opinião da narradora, de serem pronunciadas: "eu te amo". Nos anos posteriores à morte de Ana, Clara permaneceu com as lembranças ainda na memória, embora houvesse "uma parte dessa história que se esquivava de meu conhecimento" (MOSCOVICH, 2004, p. 251). Diante de uma vida repleta de escolhas em que nem sempre fora protagonista, diante de uma existência vivida mais através do olhar do outro do que do seu, Clara, finalmente, aprendera que o amor não pode ser inexpressivo. Atormentada diante da perda de seu único e grande amor, Clara narra, repetidamente, a sua própria história: "nunca mais, nos muitos anos que se seguiram, deixei de contar a mim mesma o ocorrido, narrativas reflexivas cheias de imprecisões e de fantasias impacientes" (MOSCOVICH, 2004, p. 251). Segundo Sarlo (2007, p. 19), a pessoa narra a sua vida "para conservar a lembrança ou para reparar uma identidade machucada". A narração das memórias, assim, contribui para a constituição de Clara enquanto sujeito e permite que 
assuma, para si mesma, sua identidade. Embora a narrativa termine logo após a morte de Ana, é possível perceber que esse acontecimento resultou em um aprendizado para Clara. Ela compreendeu que o amor exige expressão:

Mas algo eu soube desde então, a certeza perplexa e insofismável que sempre sucede os equívocos. Passei a reverenciar isso, minha única certeza, e a repeti-la e repeti-la para que nunca mais a força dos erros sucessivos se abatesse sobre mim. Eu soube: o amor exige expressão. Ele não pode permanecer quieto, não pode permanecer calado, ser bom e modesto; não pode, jamais, ser visto sem ser ouvido. O amor deve ecoar em bocas de prece, deve ser a nota mais alta, aquela que estilhaça o cristal e que entorna todos os líquidos. (MOSCOVICH, 2004 , p. 252, grifo nosso)

Logo, se a personagem compreendera que o amor exige expressão, é porque compreendera que a identidade exige expressão, tomada de decisões e, acima de tudo, coragem para enfrentar as consequências dessas decisões, principalmente quando as escolhas contradizem o que é socialmente esperado do sujeito. O momento em que assume seu amor por Ana, sentimento que nunca a abandonara por tantos anos, é o momento de maior transparência de subjetividade na vida de Clara. Esse fora 
um dos únicos episódios, desde que conhecera Aninha, em que Clara decidiu algo por si mesma, sem recorrer ao auxílio paterno, sem pensar no que os outros achariam disso: estava, por fim, assumindo-se enquanto sujeito afirmando sua própria identidade. De acordo com Giddens (1993), o amor está diretamente ligado às questões de identidade. Do mesmo modo, para Zinani,

o amor pode ser entendido como um fenômeno que, respeitando a autonomia dos seres, tende a reforçar a realidade individual, através do cuidado recíproco, em que cada um procura o bem do outro como seu próprio. Assim, podese afirmar que a existência do amor está condicionada a sua reciprocidade, podendo ser considerado como união de intentos, de interesses, de propósitos. Como fenômeno humano, é objetivamente constatável e muito significativo para o equilíbrio da personalidade e a conservação da identidade. (ZINANI, 2013, p. 126)

Logo, sendo o amor uma das principais bases da subjetividade humana, sua expressão faz-se imprescindível para que a relação afetiva obtenha sucesso. Se verdadeira a afirmação de Fedro de que o amor torna o homem feliz (PLATÃO, 1999), a busca pela realização amorosa e pela felicidade deve ser protagonizada pelos sujeitos, de maneira a equilibrar a personalidade e conservar a 
identidade, conforme propõe Zinani (2013). A obra Duas iguais (2004) representa essa necessidade de afirmação e expressão das relações amorosas, sejam elas homoeróticas ou não. Sendo homoeróticas precisam, muitas vezes, mais do que isso, enfrentar o preconceito social e a insegurança. $O$ resultado desse enfrentamento e posicionamento do indivíduo, sem dúvida, é benéfico tanto ao sujeito quanto às relações que ele protagoniza.

\section{REFERÊNCIAS}

BAUMAN, Zygmunt. Amor líquido: sobre a fragilidade dos laços humanos. Trad. de Carlos Alberto Medeiros. Rio de Janeiro: Zahar, 2004.

BEAUVOIR, Simone de. O segundo sexo. Trad. de Sérgio Milliet. Rio de Janeiro: Nova Fronteira, 1980. v.2.

BOURDIEU, Pierre. A dominação masculina. Trad. de Maria Helena Kühner. Rio de Janeiro: Bertrand Brasil, 2007.

BUTLER, Judith. Problemas de gênero: feminismo e subversão da identidade. Trad. de Renato Aguiar. 2ed. Rio de Janeiro: Civilização Brasileira, 2008.

CAMPOS, Maria Consuelo Cunha. Gênero. In: JOBIM, José Luiz. (Org.). Palavras da crítica. Rio de Janeiro: Imago, 1992.

CONCHE, Marcel. A análise do amor e outros temas. Trad. de Eduardo Brandão. São Paulo: Martins Fontes, 1998.

COSTA, Jurandir Freire. A inocência e o vício: estudos sobre o homoerotismo. Rio de Janeiro: Relume-Dumará, 1992.

FOUCAULT, Michel. História da sexualidade: a vontade de saber. Trad. de Maria Thereza da Costa Albuquerque e J. A. Guilhon Albuquerque. Rio de Janeiro: Edições Graal, 2005. v.1. 
. Microfísica do poder. 12ed. Trad. de Roberto Machado. Rio de Janeiro: Edições Graal, 1996.

FREUD, Sigmund. Edição standard brasileira das obras psicológicas completas de Sigmund Freud. Rio de Janeiro: Imago, 1970.

FRY, Peter; MACRAE, Edward. O que é homossexualidade. São Paulo: Brasiliense, 1991.

GIDDENS, Anthony. A transformação da intimidade: sexualidade, amor e erotismo nas sociedades modernas. Trad. de Magda Lopes. São Paulo: Editora da Universidade Estadual Paulista, 1993.

GREEN, James N. Mais amor e mais tesão: a construção de um movimento brasileiro de gays, lésbicas e travestis. Cadernos Pagu, v.15, p. 271295, 2000. Disponível em: <http://www.bibliotecadigital.unicamp.br/ document/?code=51350>. Acesso em: 6 jan. 2014.

KINSEY, Alfred C. Conduta sexual da mulher. Rio de Janeiro: Atheneu, 1955.

LAURETIS, Teresa de. A tecnologia do gênero. In: HOLLANDA, Heloisa Buarque de. (Org.). Tendências e impasses: o feminismo como crítica da cultura. Rio de Janeiro: Rocco, 1994. p. 206-242.

MOSCOVICH, Cíntia. Duas iguais. Rio de Janeiro: Record, 2004.

MOTT, Luiz. O lesbianismo no Brasil. Porto Alegre: Mercado Aberto, 1987. Por que os homossexuais são os mais odiados dentre todas as minorias? Pagu, São Paulo, Unicamp, p. 143-155, 2000. Disponível em: <http://www.pagu.unicamp.br/sites/www.ifch.unicamp.br.pagu/files/ colenc.01.a09.pdf>. Acesso em: 6 jan. 2014.

PAZ, Octavio. A dupla chama: amor e erotismo. Trad. de Wladir Dupont. São Paulo: Siciliano, 1994.

PLATÃO. Apologia de Sócrates: Banquete. São Paulo: Martin Claret, 1999. $\mathrm{RICH}$, Adrienne. Compulsory Heterosexuality and Lesbian Existence. Signs, v.5, n.4, p. 631-660, Summer 1980. Disponível em: <http://links. jstor.org/sici?sici=00979740\%28198022\%295\%3A4\%3C631\%3ACHALE\%3 E2.0.CO\%3B2-2>. Acesso em: 8 jan. 2014. 
RIOS, Roger Raupp. O conceito de homofobia na perspectiva dos direitos humanos e no contexto dos estudos sobre preconceito e discriminação. In: . Em defesa dos direitos sexuais. Porto Alegre: Livraria do Advogado Editora, 2007. p. 111-137.

SARLO, Beatriz. Tempo passado: cultura da memória e guinada subjetiva. Trad. de Rosa Freire d'Aguiar. São Paulo: Companhia das Letras; Belo Horizonte: UFMG, 2007.

SOHN, Anne-Marie. O corpo sexuado. In: CORBIN, Alain; COURTINE, JenaJacques; VIGARELLO, Georges. História do corpo: as mutações do olhar: o século XX. 3ed. Tradução Ephraim Ferreira Alvez. Petrópolis: Vozes, 2009. p. 109-154.

SOUZA, L. Processos de categorização e identidade: solidariedade, exclusão e violência. In: TRINDADE, Z. A.; SOUZA, L. (Org.). Violência e exclusão: convivendo com paradoxos. São Paulo: Casa do Psicólogo, 2004, p. 57-74. VAINFAS, Ronaldo. Homoerotismo feminino e o Santo Ofício. In: DEL PRIORE, Mary; BASSANEZI, Carla. (Org.). História das mulheres no Brasil. 9ed. São Paulo: Contexto, 2008. p. 115-140.

WITTIG, M. The straight mind and other essays. Boston: Beacon, 1992. ZINANI, Cecil Jeanine Albert. Literatura e gênero: a construção da identidade feminina. 2ed. Caxias do Sul: Educs, 2013.

Manuela Matté é Mestra em Letras, Cultura e Regionalidade, pela Universidade de Caxias do Sul. Atua como professora de Língua Portuguesa e de Língua Inglesa na rede pública municipal de ensino.

Salete Rosa Pezzi dos Santos é Doutora em Letras-Literatura Comparada, pela UFRGS. É professora e pesquisadora no Curso de Letras e no programa de Pós-graduação stricto sensu da Universidade de Caxias do Sul. É autora da obra "Duas mulheres de letras: representações da condição feminina" (2010). 